\title{
PRODUCTION OF FUEL BRIQUETTES FROM SHEA NUT SHELLS AND
} MILLET STALK

\author{
Senchi, D.S ${ }^{1}$ and Yusuf, $A^{1}$. \\ ${ }^{1}$ Department of Pure and Applied Chemistry, Kebbi State University of Science and \\ Technology, Aliero, Nigeria.
}

Corresponding Author: awalyusufmaitama@gmail.com

\begin{abstract}
In an effort to provide an affordable firewood alternative source of fuel to the rural households in Nigeria, this study was carried out to produce some biomass briquettes (Shea nut shells and millet stalk) prepared using a briquetting machine (Extruding machine). The proximate analysis of the raw samples and briquettes biomass were determined. Different samples of briquettes were produced by blending varying ratios of Shea nut shells and millet stalk of 100:0, 80:20, 70:30, 60:40, 50:50, using starch as adhesive. The results of the briquettes tested was found to have moisture content for Shea nut shell and Millet stalk $2.5 \%$ and $3.0 \%$, ash content $2.5 \%$ and $4.5 \%$ and volatile of $16.0 \%$ and $11.0 \%$. A test on physical parameters like ignition time, combustibility test and afterglow time were determined and it was observed that ignition time increases with high volatile matter and with high percentage of ash and moisture content it ignites slowly. Water boiling test was also performed to compare between butane gas and fuel briquettes, it was observed that both butane gas and briquettes took the same time to boil 2litre of water (18 minutes).
\end{abstract}

Keywords: Biomass, Density, $\mathrm{CO}_{2}$, Briquetting, Combustion. 


\section{INTRODUCTION}

The decreasing availability of domestic fuel like wood, charcoal and the ever-rising of kerosene and cooking gas in Nigeria, has drawn the attention to the need to consider alternative sources of energy for domestic and cottage level industrial use in the country (Lucas and Akinoso, 2001). Wood, charcoal had been the major source of renewable energy in Nigeria, accounting for about $51 \%$ of the total annual energy consumption (Olorunnisola, 2004). The over-reliance of forest wood in Nigeria mainly for charcoal production, fire wood and furniture making had resulted in the depletion of forest reserves at a faster rate. A similar scenario, according to (Emerhi, 2011), in other sub- Saharan countries had resulted in shortage of fuel wood which led to the depletion of over $75 \%$ of the total forest cover and thus leading to environmental crises. As rightly noted by (Stout and Best, 2001), a transition to a sustainable energy is urgently needed for developing countries (Emerhi, 2011). Fuel briquettes have shown great promise in solving this problem. This is the type of technology that generates energy from municipal and biomass wastes, through the application of high pressure by machines with or without a binding agent. It involves drying, shredding, grinding and pressing biomass wastes into various briquette sizes and shapes (Ramesh, 2005). However, the performance of any solid biomass fuel such as sawdust briquette is evaluated effectively when it is combusted (Adegoke, 1999). The energy content of the briquettes varies depending on the materials used. It is thus important to assess the energy values of some of the briquettes made from some of these readily available agricultural by-products with a view to ascertained the economic viability of embarking on mass production of Comparative Assessment of Energy Values of Briquettes.Recent research and future predictions has shade light to the fact that crude oil might run out within 40 to 70 years from now and natural gases have the possibility of finishing in 50 years.Thus, global average temperature was predicted to have increased from $1.4^{\circ} \mathrm{C}$ to about $5.8^{\circ} \mathrm{C}$ by the year 2100 and may continue to increase with time. Several investigations pointed out that natural disasters like drought, increase in hurricane and tornadoes, flooding and wide spread crop failure are likely to be inevitable.

Thus, the increase in the concentration of greenhouses gases $\left(\mathrm{CO}_{2}\right.$ and others $)$ in the atmosphere are emitted mainly by the combustion of fossil fuels, containing carbon like natural gases, crude oil and so on. And the rising of greenhouse gases emission, decreasing fossil fuel supplies and energy security has led to the introduction of renewable energy as main target at national level (Elinge et al., 2011).

The aim of this study is to convert cheap agricultural waste (Shea nut shell and Millet stalk) in a solid fuel biomass briquettes and to compare and analyze the thermo-physical properties of Shea nut shell and millet stalk briquettes under similar condition, with a view to finding out the most reliable of these waste products as raw material for briquette making that would serve as energy source for domestic cooking, heating and lighting.

\section{MATERIAL AND METHODS}

Sample Collection: Samples of dried Shea nut shell and Millet stalk were collected from Zuru Local Government Area, while cassava starch was purchased at the Zuru Central Market, Kebbi State. 
Preparation of the Sample: The collected samples were sun-dried for three days and then pulverized and sieved with $2.5 \mathrm{~mm}$ mesh sieve to obtain a fine particle size. The samples were kept in a polyethylene bag until required for preparation of briquettes.

Preparation of Briquettes: The biomass briquettes were formulated using different percentage of Shea nut shells and millet stalk of 100:00, 80:20, 70:30, 60:40, and 50:50 and the quantity of the starch used was $25 \mathrm{~g}$ of the whole briquettes. It was mixed thoroughly until a homogeneous mixture was obtained. A cylindrical mould of $16 \mathrm{~cm}$ in length and $2.5 \mathrm{~cm}$ internal diameter was constructed. A metal bar of $2.5 \mathrm{~cm}$ diameter was used in pushing the formed briquettes out of the moulding cylinder. The produced briquettes were air dried for three weeks as recommended by (Elinge et al., 2011).

\begin{tabular}{lccccc}
\hline Raw Materials & $100: 0$ & $80: 20$ & $70: 30$ & $60: 40$ & $50: 50$ \\
\hline Starch (g) & 25 & 25 & 25 & 25 & 25 \\
Biomass (g) Shea nut shells & 100 & 80 & 70 & 60 & 50 \\
Biomass (g) Millet stalk & 100 & 80 & 70 & 60 & 50 \\
Water (g) & 250 & 250 & 250 & 250 & 250
\end{tabular}

Moisture Content: Moisture content of the briquette samples was determined based on weight measurement before and after oven drying. $2 \mathrm{~g}$ of the sample was measured out (initial weight of the sample before drying) the sample and the crucible were placed in a drying oven set at $105^{\circ} \mathrm{C}$ for $24 \mathrm{hrs}$. The crucible and its content were removed and placed in desiccators to cool at room temperature and re-weighed. The process was repeated until the weight after cooling is constant, and recorded as the final weight (final weight of the sample after oven drying) (Adekunle et al., 2015).

$$
\text { Moisture Content }(\%)=\frac{\text { Initial Weight of Sample }- \text { Final weight of Sample }}{\text { Initial Weight of Sample }} \times 100
$$

Ash Content: Ash content of the sample briquettes was determined using a furnace residue from fixed carbon determination and was heated in a furnace ignited at $590^{\circ} \mathrm{C}$, for $2 \mathrm{hrs}$ and transferred into desiccators to cool down the material that was turned into white ash and weighed. Same process was repeated three times at $1 \mathrm{hr}$ interval until the weight is constant. The weight was 
recorded as the final weight of the ash (Adekunle et al., 2015). The percentage ash content was calculated using equation below:

$$
\text { Ash Content }(\%)=\frac{\text { Weight of Ash }}{\text { Initial Weight of dry Sample }} \times 100
$$

Fixed Carbon: The fixed carbon represents the amount of carbon that can be burnt by a primary current of air drawn through the hot bed of fuel (Moore and Johnson, 1999). The fixed carbon of the sample was determined using the following equation.

$$
\text { Fixed Carbon Content }=100-[(M C \%)+(V M \%)+(A C \%)]
$$

Where:

$$
\begin{aligned}
& \mathrm{MC}=\text { Moisture Content } \\
& \mathrm{VM}=\text { Volatile Matte } \\
& \mathrm{AC}=\text { Ash Content }
\end{aligned}
$$

Volatile Matter: The briquettes percentage volatile matter content was determined using Lenton furnace. The residue of the dry sample from moisture content determination was preheated at $300^{\circ} \mathrm{C}$ for $2 \mathrm{hrs}$ to drive off the volatiles, the resulting sample was further heated at $470^{\circ} \mathrm{C}$ for $2 \mathrm{hrs}$, to remove volatile matter, just before the sample were turned to ashes, and then cooled in desiccators (Adekunle et al., 2015). The crucible with known weight and its content were weighed and as the percentage of weight loss, the percentage volatile matter was calculated using the equation below.

$$
\text { Volatile matter }(\%)=\frac{\text { FinalWeight }}{\text { OriginalWeight }} \times 100
$$

Ash Content: Ash content of the sample briquettes was determined using a furnace residue from fixed carbon determination and was heated in a furnace ignited at $590^{\circ} \mathrm{C}$, for $2 \mathrm{hrs}$ and transferred into desiccators to cool down the material that was turned into white ash and weighed. Same process was repeated three times at $1 \mathrm{hr}$ interval until the weight is constant. The weight was recorded as the final weight of the ash (Adekunle et al., 2015). The percentage ash content was calculated using equation below. 


$$
\text { Ash Content }(\%)=\frac{\text { Weight of Ash }}{\text { Initial Weight of dry Sample }} \times 100
$$

Where:

$\mathrm{MC}=$ Moisture Content

$\mathrm{VM}=$ Volatile Matte

$\mathrm{AC}=$ Ash Content

Fibre Content: $2 \mathrm{~g}$ of the sample was weighed and put into a cornical flask labelled Wo, $200 \mathrm{ml}$ of $\mathrm{NaOH} 1.25 \%$ was added and boiled for 30 minutes after cooling it was filtered and rinsed with hot distilled water and also $10 \% \mathrm{HCl}$ and twice with ethanol of small quantity. Then finally rinsed with petroleum ether. After it drained, the residue was scraped into a crucible and dried over night at $105^{\circ} \mathrm{C}$ in the oven and cooled in a desiccator, the sample was weighed and labelled $\mathrm{W}_{1}$, The sample was ashed at $550^{\circ} \mathrm{C}$ for 90 minutes in a muffle furnace then cooled in a desiccator and weighed again as $\mathrm{W}_{2}($ Bakare, 1985).

The $\%$ fibre content was calculated as: $\%$ fibre $=\frac{W 1-W 2}{w 0} \times 100$

Nitrogen Content: This was determined based on the kjeldhal procedure and crude protein value was obtained by multiplying the nitrogen value by a factor of 6.5 while estimate of available carbohydrates was done by difference as: $\mathrm{CHO}=100-(\% \mathrm{Ash}+\% \mathrm{CP}+\% \mathrm{CL}+\%$ Fibre $)$.

Where: $\mathrm{CHO}, \mathrm{CP}$, and $\mathrm{CL}$ stands for Carbohydrate, Crude protein and Crude lipids.

Lipid content: $2 \mathrm{~g}$ of the sample was weighed into a labelled porous thimble and covered with clean white cotton wool, $200 \mathrm{ml}$ of petroleum ether was measured and put into dry $250 \mathrm{ml}$ dried extraction flask, the covered porous thimble was placed into the condenser and assemble the apparatus and extracted for 6 hours, the sample was then removed from water bath after it was petroleum ether free. The extraction flask containing the lipid at $105^{\circ} \mathrm{C}-110^{\circ} \mathrm{C}$ was heated for 1 hour, and then cooled in a desiccator, the weight after cooling was noted (Bakare et al., 1985).

$$
\% \text { of lipid }=\frac{\mathrm{W} 3-\mathrm{W} 2}{\mathrm{~W} 1} \times 100
$$

Key: $\mathrm{W}_{0}$ - weight of the porous thimble, $\mathrm{W}_{1}$ - weight of thimble + sample, $\mathrm{W}_{1}-\mathrm{W}_{0}$ - weight of sample, $\mathrm{W}_{2^{-}}$weight of empty extraction flask, $\mathrm{W}_{3^{-}}$weight of extraction flask+ ether.

Compressive Strength: The compressive strength of the briquette was determined using a compressive testing machine. The length and the width of the briquette was measured and recorded. The machine was on and allowed to warm up for 4 minutes. The sample was placed on 
the movable bed, and the control lever was applied upward to bring contact between the upper fixed bed and the movable lower bed on which the samples was put on. The reading was taken the moment the crack was noticed in the briquette samples showing that the sample is compressed. The value of the reading was recorded.

$$
\text { Compressive strength }=\frac{\text { compressive force }(F t)}{\text { cross sectional area of the sample }(A c)}
$$

Where: cross sectional area $=$ Length $\times$ Width

Density: The density of the briquettes was determined using a weighing balance by taking the weight of all the briquettes samples and dimension measurement using a vernier caliper. The volume was calculated using $\pi \mathrm{r}^{2} \mathrm{~h}$.

$$
\text { Density }=\frac{\operatorname{Mass}(g)}{\operatorname{Volume}\left(\mathrm{cm}^{3}\right)}
$$

Where: $\boldsymbol{\pi}=$ Pie, $\mathbf{r}=$ radius, $\mathbf{h}=$ height

Ignition Time: Ignition time was determined as reported by Oladeji (2010). The samples were graduated in centimeters, ignited at the base and allowed to burn until it extinguished itself. The rate at which flame propagated was calculated by dividing the distance burnt by the time taken in seconds.

$$
\text { Ignition time }=\frac{\text { distance burnt }(\mathrm{mm})}{\text { total time taken }(\mathrm{sec})}
$$

Burning Rate: Briquettes burning rate was determined by recording the briquettes weight before combustion and after the briquettes were completely burnt, the rate at which fire consumed the briquette samples were calculated using equation (Onuegbu et al., 2011).

$$
\text { Burning Rate }=\frac{\text { mass of total fuel comsumed }(g)}{\text { total time taken }(\min )}
$$

Combustibility Test: Water Boiling Tests was conducted by combusting $100 \mathrm{~g}$ of briquettes of different percentage of binders (gum arabic and starch) samples respectively using charcoal stove to compare the fuel combustibility and the fuel that cooked food faster. 2 litres of water was used for the test. The temperature reading was taken after every 2 minutes with mercury in glass thermometer (Kim et al., 2001) until the water boil. The time taken by each sample to boiled water was monitored using stop watch. 
International Journal of Advanced Academic Research (Sciences, Technology and Engineering) | ISSN: 2488-9849

Journal DOI: 10.46654/ij.24889849

Article DOI: 10.46654/ij.24889849.e61013

\section{RESULTS AND DISCUSSION}

Table 1: Physicochemical Properties of the Raw Sample

\begin{tabular}{lcc}
\hline Sample test & SN $(\%)$ & MS (\%) \\
\hline Moisture content & $3.0 \pm 0.5$ & $10.5 \pm 0.5$ \\
Ash content & $2.5 \pm 0.5$ & $4.0 \pm 0.5$ \\
Lipid & $5.5 \pm 0.1$ & $3.0 \pm 0.1$ \\
Fiber & $1.5 \pm 0.1$ & $1.5 \pm 0.1$ \\
Nitrogen & $1.42 \pm 0.02$ & $0.87 \pm 0.01$ \\
Volatile matter & $10.5 \pm 0.5$ & $7.0 \pm 0.5$ \\
Carbon content & $75.5 \pm 0.5$ & $86.0 \pm 0.01$ \\
\hline
\end{tabular}

Values above are mean value of standard deviation of triplicate results

\section{Keywords:}

$\mathrm{SN}=$ Shea nut shells

MS= Millet stalks 
International Journal of Advanced Academic Research (Sciences, Technology and Engineering) | ISSN: 2488-9849

Vol. 6, Issue 10 (October, 2020) | www.ijaar.org

Journal DOI: 10.46654/ij.24889849

Article DOI: 10.46654/ij.24889849.e61013

Table: 2. Physico-Chemical Properties of the Briquettes

\begin{tabular}{|c|c|c|c|c|c|c|c|}
\hline \multirow{3}{*}{$\begin{array}{l}\text { Sample } \\
\text { Ratio }\end{array}$} & \multirow{3}{*}{$\begin{array}{l}\text { Ash } \\
\text { Content (\%) } \\
2.5 \pm 0.5\end{array}$} & \multicolumn{2}{|c|}{ Volatile Nitrogen $(\%)$} & Carbon $(\%) \quad$ Lipid (\%) & \multicolumn{2}{|c|}{ Combustibility Test } & \\
\hline & & Matter (\%) & & & & & \\
\hline & & $16.0 \pm 0.5$ & $1.344 \pm 0.002$ & $83.0 \pm 0.01$ & $3.5 \pm 0.5$ & 20 & \\
\hline MS (100:0) 3.0 \pm 0.1 & $4.5 \pm 0.5$ & $11.0 \pm 0.5$ & $1.414 \pm 0.002$ & $77.0 \pm 0.01$ & $4.0 \pm 0.5$ & 22 & \\
\hline SN/MS (80:20) & $1.5 \pm 0.1$ & $3.5 \pm 0.5$ & $15.0 \pm 0.5$ & $1.302 \pm 0.002$ & $79.5 \pm 0.05$ & $3.5 \pm 0.1$ & 18 \\
\hline SN/MS (70:30) & $3.5 \pm 0.1$ & $3.5 \pm 0.5$ & $15.0 \pm 0.5$ & $1.792 \pm 0.002$ & $77.5 \pm 0.05$ & $4.5 \pm 0.1$ & 22 \\
\hline SN/MS (60:40) & $3.0 \pm 0.5$ & $4.0 \pm 0.1$ & $10.0 \pm 0.5$ & $1.106 \pm 0.002$ & $81.5 \pm 0.05$ & $3.0 \pm 0.5$ & 18 \\
\hline SN/MS (50:50) & $4.0 \pm 0.5$ & $4.0 \pm 0.1$ & $10.0 \pm 0.5$ & $1.092 \pm 0.002$ & $82.5 \pm 0.02$ & $3.0 \pm 0.5$ & 22 \\
\hline Butane gas & & & & & & & 18 \\
\hline
\end{tabular}

Values above are mean value of standard deviation of triplicate results

\section{Keywords:}

$\mathrm{SN}=$ Shea nut shells

MS $=$ Millet stalks 
Table: 3. Viability Test Results of Briquette Sample

\begin{tabular}{lcccc}
\hline $\begin{array}{l}\text { Sample } \\
\text { Ratio }\end{array}$ & Strength $\left(\mathrm{N} / \mathrm{mm}^{2}\right)$ & $\begin{array}{c}\text { Afterglow time } \\
(\mathrm{s})\end{array}$ & \multicolumn{2}{l}{ Ignition time $(\mathrm{cm} / \mathrm{s})$ Density $\left(\mathrm{g} / \mathrm{cm}^{3}\right)$} \\
\hline SN(100:0) & 2.60 & 20 & 0.10 & 0.60 \\
MS (100:0) & 0.58 & 47 & 0.07 & 0.31 \\
$80: 20$ & 1.46 & 0.16 & 0.49 & 0.43 \\
$70: 30$ & 1.58 & 0.13 & 0.83 & 0.46 \\
$60: 40$ & 1.46 & 38 & 0.17 & 0.42 \\
$50: 50$ & 2.12 & 36 & 0.08 & 0.40
\end{tabular}

Values above are mean value of standard deviation of triplicate results

\section{Keywords:}

$\mathrm{SN}=$ Shea nut shells

MS= Millet stalks

Discussion: The results of the proximate analysis of the raw sample shows that the millet stalk has high value of moisture content of (10.5\%), ash (5.0\%) and low volatile matter of (7.0\%) compared to the Shea nut shells which has lower moisture content of $(3.0 \%)$, ash $(2.5 \%)$ and high volatile matter of $(10.4 \%)$. The high ash content of millet stalk shows that it contains more mineral(non-combusible) matters than Shea nut shells This by implication Shea nut shells will ignite more readily and burn faster than millet stalk due to the amount of the volatile matter it has (Loo and Koppejan, 2008). High amount of moisture shows that it will produce steam and could result to expulsion (Grover and Mishra, 1996). Moisture content has an important role to play as it hinders heat transfer. It is clearly shown in Table 1. The value of moisture con tent of Shea nut shells $(2.5 \%)$ is lower than that of millet stalk $(3.0 \%)$. This was also seen in the blends Shea nut shell/ millet stalk ratio of 80:20 (1.5\%) and 70:30 (3.5\%), where the percentage of Shea nut shell contains high moisture content compared to ratio $60: 40$ and 50:50 which the value is $3.0 \%$ and $4.0 \%$ respectively. These results are within the recommended standard limit of $15 \%$ as reported by Walaipon (2008) for briquetting of agro-residues. This shows that briquetting generally reduces moisture content and enhances the energy content and the combustibility of the fuel briquettes (Walaipon, 2008).

It is obvious that Shea nut shells have high volatile matter (16.0\%) while millet stalk has the lower value of $(11.0 \%)$. The same was noticed in the blends Shea nut shells / millet stalk ratios where the percentage of Shea nut shell is high the amount of the volatile matter is high as seen in Table 1. In ratio 70:30 and 80:20 which have the values of $15.0 \%$ respectively than those ratio of 60:40 (11.0\%) and 50:50 (10.0\%) where the Shea nut shell is low. This makes Shea nut shell 
briquettes highly reactive fuel giving fast combustion rate during devolatisation phase than millet stalk (Loo and Koppejan, 2008). As reported by Chaney,(2010) low-grade fuels, tend to have low volatile content that results in smoldering which De Souza and Sandberg(2004) described as an incomplete combustion which leads to a significant amount of smoke and result of toxic gases. High volatile matter indicates the relative ease of ignition of the briquettes and the proportionate increase in flame length as reported by (Loo and Koppejan, 2008). The high volatile matter indicated that during combustion, Shea nut shells briquettes and blends of 70:30 and 80:20 would volatilize and burn better.

Ash is the non- combustible component of biomass. Shea nut shell contain $2.5 \%$ while millet stalk has $4.5 \%$ briquettes and the blends of Shea nut shells/ millet stalk ratios of 80:20 and 70:30 has the ash content of 3.5\% respectively and that of 60:40, 50:50 has 4.0\% respectively. Kim et al., 2001 reported that ash has a significant influence on the heat transfer to the surface of a fuel as well as the diffusion of oxygen to the surface during combustion. Since ash is an impurity that would not burn, fuels with low ash content are better suited for thermal utilization than fuels with high ash content. By implication shea nut shells and it blends of 80:20 and 70:30 are better briquettes than millet stalk and it blend of 60:40 and 50:50 because of the low ash content. High ash content in a fuel usually leads to higher dust emissions and affects the combustion volume and efficiency (Loo and Koppejan, 2008).

Millet stalks boils 2 litres of water in 24 minutes while Shea nut shells took 20 minutes to boil the same quantity of water; this indicates that Shea nut shell has high rate of combustion than millet stalk. This is also noticed in the blends of Shea nut shells/ millet stalk of 70:30 and 80:20 which took 18 minutes to boil 2 litres of water. Since Shea nut shells briquettes have low moisture content, high volatile matter and good combustion efficiency it can also be seen that blending reduces the time taken which could be as a result of dense nature of the briquettes as shown by the stress value, as shown in the ratio of 70:30 and 80:20 which took 18 minutes to boil water.

The afterglow times of 20sec. and $47 \mathrm{sec}$. were recorded for Shea nut shells and millet stalk briquettes and for the blends of Shea nut shells/millet stalk the following values were observed; 80:20 (24 sec.) 70:30 (38 sec.) and 50:50 (36sec.) while the propagation rates (flame propagation) of $0.10 \mathrm{~cm} / \mathrm{s}$ and $0.12 \mathrm{~cm} / \mathrm{s}$ were obtained for briquettes of Shea nut shell and millet stalk respectively and for the blended briquettes of Shea nut shell/millet stalk the values of afterglow time were obtain as these; 80:20 (24sec.), 70:30 (30sec.), 60:40 (38sec.) and 50:50 (36sec.). Comparing the results, longer afterglow time and slow propagation rate for Shea nut shells briquette imply that Shea nut shell briquettes will ignite more easily and burn with intensity for a long time than millet stalk.

The compressive strengths for the two feed stock were found to be reasonable, the briquettes from Shea nut shell have the higher value of $2.60 \mathrm{KN} / \mathrm{M}^{2}$. Similarly for the blends of Shea nut shells/ millet stalk the ratio of $50: 50\left(2.12 \mathrm{KN} / \mathrm{M}^{2}\right)$ was observed to have high value for compressive strength than the corresponding ratios of $80: 20\left(1.46 \mathrm{KN} / \mathrm{M}^{2}\right), 70: 30\left(1.58 \mathrm{KN} / \mathrm{M}^{2}\right)$, and 60:40 $\left(1.46 \mathrm{KN} / \mathrm{M}^{2}\right)$. This implies that, briquettes from Shea nut shells and even blends of 80:20, 70:30, and 60:40 will not suffer damage during transportation and storage than millet stalk briquettes that have just $0.5 \mathrm{KN} / \mathrm{M}^{2}$. 
Journal DOI: 10.46654/ij.24889849

Vol. 6, Issue 10 (October, 2020) | www.ijaar.org

Article DOI: 10.46654/ij.24889849.e61013

During the briquetting of both categories of waste, it was found that high compacting pressure is necessary in order to achieve good and stable briquettes. Density is important parameter which characterized the briquetting process. Density of the briquettes is proportional to the energy ratio. Hence high density is required in order to ease their transportation, storage and handling.

Conclusion: The briquettes produced from Shea nut shells and millet stalk would make a good biomass fuels. However from the study it can be concluded that briquettes produced from Shea nut shells shows more desirable positive attributes of biomass fuel than millet stalk and the combination of the two biomass can produce the same or better, efficiency as gas. The simulation results show that the blended briquettes were comparable to gas in their performance and the simulation suggested that the briquettes could even perform better than gas. 


\section{References}

Adegoke, C.O. (1999). A Preliminary investigation of sawdust as high grade solid Fuel, Nigeria Journal of Renewable Energy.

Adekunle, J.O. Ibrahim, J.S. and Kucha, E.I. (2015). Proximate and Ultimate Analysis of Biocoal Briquettes of Nigeria's Ogboyaga and Okaba Sub-Bituminous coal. British Journal of Applied Science and Technology.Vol. 7 (1) Pp 114-123.

Bakare (1985). Methods of Biochemical Analysis of plant tissues. Agronomy Department University of Ibandan.

Elinge, C. M., Itodo, A., Yusuf, H., Birnin-Yauri, U.A. and Mbongo, A. N. (2011). Blending Coal char on the Combustion Profiles of Fuel Briquettes. Pelagia Research Library.Vol.2 (4) Pp. 152-157.

Emerhi E.A. (2011). Physical and Combustion Properties of Briquettes Produced from Saw dust of three hardwood species and different organic binders Advanced in Applied Science Research. Vol .2 (6) Pp 236-246.

Grover, P. D. and Mishra, S. K. (1996). Biomass Briquetting: Technology and Practices; Field Document no. 46, Food and Agricultural Organization of the United Nations, Bangkok, 1996.

Kim, H., Kazuhiko, S. and Masayoshi, S. (2001). Biomass Briquette as a Technology for Desulphurizing and Energy Saving, Renewable Energy Journal.Vol. 8 Pp 33-75.

Loo, S.V. and Koppejan, J., (2008). The Handbook of Biomass Combustion and Co-firing, Earthscan Publishers, Calcutta, pp. 67-70.

Lucas, E.B and Akinoso, R. (2001). A Solar Device for Crop Drying and Cooking. Proceeding of International conference of Agricultural Engineers. Vol.23:395.

Moore, W. and Johnson, D. (1999). Procedure for the Chemical Analysis of Wood and Wood Products, Modison WL: US. Forest Products Laboratory, Department of Agriculture.

Oladeji, J.T. (2010). Fuel Characterization of Briquettes Produced from Corcob and Rice husk Residues. The Specific Journal of Science and Technology. Vol. 2 (1) Pp101-106.

Olorunnisola, A.O. (2004). "Briquetting of rattan furniture waste". Journal of Bamboo and Rattans. Vol. 3(2) Pp 139-149.

Onuegbu,T.U., Ekpunobi, U.E., Ogbu, I.M., Ekeoma, M.O., and Obumselu, F.O., (2011). Comparative Studies of Ignition Time and Water boiling Test of Coal and Biomass Briquettes Blend. IJRRAS. Vol. 7 (2) Pp 153-159.

Ramesh, N. (2005). Energy wise. A Burning Concerne- India. Chandigrah 160Series 7: Programme 1 of 8 . 
International Journal of Advanced Academic Research (Sciences, Technology and Engineering)| ISSN: 2488-9849

Journal DOI: 10.46654/ij.24889849

Vol. 6, Issue 10 (October, 2020) | www.ijaar.org

Article DOI: 10.46654/ij.24889849.e61013

Stout, B.A. and G. Best 2001. Effective energy use and climate change: needs of rural areas in developing countries. Agricultural Engineering International: the CIGR E-Journal of Scientific Research and Development. Vol. III, 19pp.

Wilaipon, P. (2008). Density Equation of Bio-Coal Briquette and Quantity of Maize Cob in Phitsanulok, Thailand. American Journal of Applied Sciences. Vol. 5(2) Pp 1808-1811. 